Check for updates

Cite this: RSC Adv., 2017, 7, 40105

8th June 2017

Accepted 8th August 2017

DOI: $10.1039 / \mathrm{c} 7 \mathrm{ra06438a}$

rsc.li/rsc-advances

\title{
Evaluation of different buffer materials for solar cells with wide-gap $\mathrm{Cu}_{2} \mathrm{ZnGeS}_{x} \mathrm{Se}_{4-x}$ absorbers $\dagger$
}

\author{
T. Schnabel, (D) *a M. Seboui, ${ }^{\text {a A. Bauer, }}{ }^{\text {a L. Choubrac, }}{ }^{\text {b }}$ L. Arzel, ${ }^{\text {b }}$ S. Harel, ${ }^{\text {b N. Barreau }}{ }^{\text {b }}$ \\ and E. Ahlswede ${ }^{a}$
}

In this work kesterite-type $\mathrm{Cu}_{2} \mathrm{ZnGeS}_{x} \mathrm{Se}_{4-x}$ (CZGSSe) absorbers were coated with four different buffer layer materials: $\mathrm{CdS}, \ln _{2} \mathrm{~S}_{3}, \mathrm{Zn}(\mathrm{O}, \mathrm{S})$ and $\mathrm{Cdln}_{2} \mathrm{~S}_{4}$. A detailed electrical characterization of the resulting solar cells was performed. The highest open-circuit voltage and the best band alignment could be reached with $\mathrm{Zn}(\mathrm{O}, \mathrm{S})$, whereas the CdS buffer gave the best efficiencies of up to $6 \%$, which is the highest reported efficiency for a CZGSSe absorber.

\section{Introduction}

In recent years, $\mathrm{Cu}_{2} \mathrm{ZnSnS}_{x} \mathrm{Se}_{4-x}$ (CZTSSe) has gained significant attention as an absorber material for thin-film solar cells with the intention to substitute the more mature $\mathrm{CuIn}_{y} \mathrm{Ga}_{1-y} \mathrm{Se}_{2}$ (CIGS). However, solar cells with CZTSSe absorber still suffer from a high open-circuit voltage $\left(V_{\mathrm{OC}}\right)$ deficit that is drastically limiting to the efficiency.

One approach to overcome this limitation is the substitution of Ge for Sn which increases the band gap and has been found to improve the crystallinity of the absorber ${ }^{1}$ and reduce the amount of $\mathrm{Sn}^{2+}$-related defects. ${ }^{2}$ Significant improvements of $V_{\mathrm{OC}}$ and efficiency have been reported for adding a small amount of Ge as dopant. ${ }^{3}$ For mixed $\mathrm{Cu}_{2} \mathrm{ZnSn}_{y} \mathrm{Ge}_{1-y} \mathrm{~S}_{x} \mathrm{Se}_{4-x}$ absorbers efficiencies exceeding $10 \%$ have been reported for $[\mathrm{Ge}] /([\mathrm{Sn}]+[\mathrm{Ge}])$-ratios between 0.25 and $0.4,{ }^{4-6}$ some of them with a drastically improved $V_{\mathrm{OC}}{ }^{4}$ Consequently, the interest in a complete substitution of $\mathrm{Ge}$ for $\mathrm{Sn}$ is also rising, which allows the possible use as a wide band gap top cell in tandem solar cells with a tunable band gap between 1.4 and $2.0 \mathrm{eV} .^{7,8}$ So far there are only few manuscripts reporting on the structural and optical characterisation of $\mathrm{Cu}_{2} \mathrm{ZnGeS}_{x} \mathrm{Se}_{4-x}$ (CZGSSe) ${ }^{7,9,10}$ and some first reports about solar cells. ${ }^{11,12}$ In previous manuscripts, we could demonstrate efficiencies exceeding $5 \% .{ }^{12,13}$

However, since CdS has a decent spike-like band alignment with CZTSSe ${ }^{\mathbf{1 4 , 1 5}}$ and the conduction band minimum (CBM) of CZGSe was reported to be about $0.5 \mathrm{eV}$ higher than that of CZTSe,${ }^{16}$ it is expected to have a non-ideal band alignment with the CZGSSe absorber. In addition for environmental reasons the use of a Cd-free buffer material would be favourable.

${ }^{a}$ Zentrum für Sonnenenergie- und Wasserstoff-Forschung Baden-Württemberg, Meitnerstraße 1, 70563 Stuttgart, Germany.E-mail: thomas.schnabel@zsw-bw.de

${ }^{b}$ Institut des Materiaux Jean Rouxel (IMN), Universitéde Nantes, CNRS, 2 rue de la Houssiniere, BP 32229, 44322 Nantes Cedex 03, France

$\dagger$ Electronic supplementary information (ESI) available. See DOI: 10.1039/c7ra06438a
Therefore, in this work four different buffer layer materials are compared: CdS, $\mathrm{Zn}(\mathrm{O}, \mathrm{S}), \mathrm{In}_{2} \mathrm{~S}_{3}$ and $\mathrm{CdIn}_{2} \mathrm{~S}_{4}$. The first three of them are well-established buffer materials with reported efficiencies for CIGS exceeding $22 \%,{ }^{17} 21 \%{ }^{18}$ and $18 \%,{ }^{19}$ respectively. In contrast, $\mathrm{CdIn}_{2} \mathrm{~S}_{4}$ is a rather new candidate that was found as reaction product at the interface between CdS and KF-treated CIGS $^{20}$ and might therefore be linked to the efficiency improvement that is gained from the KF-treatment.

\section{Experimental}

The CZGSSe absorbers were prepared from a metal salt solution that consists of copper(I)-chloride $(0.46 \mathrm{M})$, zinc(II)-chloride $(0.32 \mathrm{M})$, germanium(Iv)-chloride $(0.31 \mathrm{M})$ and thiourea $(1.48 \mathrm{M})$ with dimethyl formamide as solvent. The chemical composition is chosen to be $\mathrm{Cu}$-poor with metal ratios of $\mathrm{Cu} /(\mathrm{Zn}+\mathrm{Ge})=0.7$ and $\mathrm{Zn} / \mathrm{Ge}=1.0$. The solution is deposited onto a molybdenumcoated soda lime glass substrate by doctor-blade coating and a subsequent drying step. The resulting layer is annealed in Seatmosphere at $550{ }^{\circ} \mathrm{C}$ to exchange $\mathrm{S}$ for Se and induce the crystallisation. Further details on the absorber formation can be found in ref. 12.

The CdS buffer layer with a thickness of approximately $50 \mathrm{~nm}$ was deposited by chemical bath deposition (CBD) from $\mathrm{CdSO}_{4}, \mathrm{NH}_{4} \mathrm{OH}$ and thiourea. $\mathrm{Zn}(\mathrm{O}, \mathrm{S})$ layers were deposited by sputtering from mixed $\mathrm{Zn}(\mathrm{O}, \mathrm{S})$ targets with $[\mathrm{S}] /([\mathrm{S}]+[\mathrm{O}])$-ratios of 0.2 (layer thickness $67 \mathrm{~nm}$ ) and 0.4 (layer thickness $41 \mathrm{~nm}$ ). $\mathrm{In}_{2} \mathrm{~S}_{3}$ layers were grown by atomic layer chemical vapour deposition (ALCVD) at $210{ }^{\circ} \mathrm{C}$ from indium(III)-acetylacetonate and hydrogen sulphide. The film thickness was varied between $3 \mathrm{~nm}$ and $28 \mathrm{~nm}$ by adjusting the number of deposition cycles. To improve the quality of the interface, subsequent heat treatments in ambient atmosphere on a hot plate were performed at temperatures between $180{ }^{\circ} \mathrm{C}$ and $220{ }^{\circ} \mathrm{C}$. $\mathrm{CdIn}_{2} \mathrm{~S}_{4}$ layers were grown by coevaporation of $\mathrm{CdS}$, In and $\mathrm{S}$ resulting in a layer thickness of $50 \mathrm{~nm}$. 


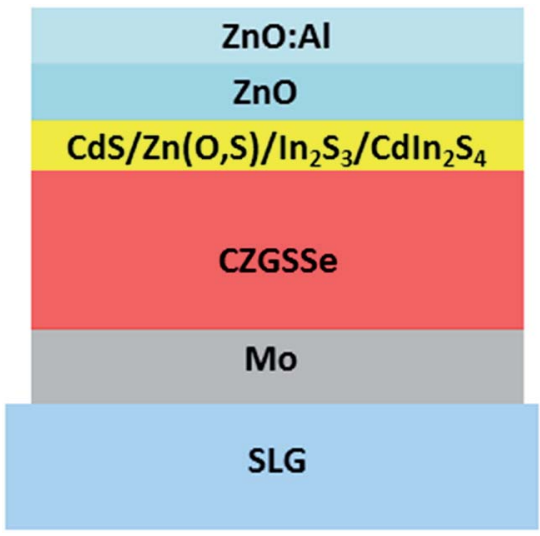

Fig. 1 Schematic drawing of the layer stack of a complete solar cell.

To obtain functional solar cells, the samples are completed with a sputtered undoped $\mathrm{ZnO}(\mathrm{i}-\mathrm{ZnO}, 40 \mathrm{~nm}$ ) and an aluminium-doped $\mathrm{ZnO}$ (ZAO, $400 \mathrm{~nm}$ ) layer and separated to single cells of $0.25 \mathrm{~cm}^{2}$ each by mechanical scribing. A schematic illustration of the layer stack is displayed in Fig. 1. For samples with a CdIn ${ }_{2} \mathrm{~S}_{4}$ buffer, $40 \mathrm{~nm}$ of $\mathrm{i}-\mathrm{ZnO}$ and $180 \mathrm{~nm}$ of $\mathrm{ZAO}$ were used followed by a $\mathrm{Ni} / \mathrm{Al} / \mathrm{Ni}$ grid, the device area here is $0.5 \mathrm{~cm}^{2}$.

Current-voltage curves were measured using a Keithley 2400 source measuring unit under simulated AM 1.5 global solar irradiation with an WACOM 2-lamp sun simulator at $100 \mathrm{mWcm}^{-2}$. Temperature-dependent current-voltage (JV)characteristics were measured with a Peltier cooling element in a temperature range from $10{ }^{\circ} \mathrm{C}\left(17{ }^{\circ} \mathrm{C}\right.$ for $\left.\mathrm{CdIn}_{2} \mathrm{~S}_{4}\right)$ to $60{ }^{\circ} \mathrm{C}$. External quantum efficiency (EQE) measurements were performed with a setup from Optosolar.

\section{Results}

As described in the experimental section, variations of film thickness, heat treatment and composition have been performed for $\operatorname{In}_{2} \mathrm{~S}_{3}$ and $\mathrm{Zn}(\mathrm{O}, \mathrm{S})$ buffers. Therefore, these variations are described in the following subsections, before all four buffer materials are compared in the final subsection.

\section{$\operatorname{In}_{2} \mathbf{S}_{3}$}

There are numerous reports about $\operatorname{In}_{2} S_{3}$ as a buffer material for CZTSSe absorbers. For $\mathrm{Cu}_{2} \mathrm{ZnSnSe}_{4}$ (CZTSe) efficiencies of $5.7 \%$ haven been achieved with $\operatorname{In}_{2} \mathrm{~S}_{3}$ deposited by co-evaporation ${ }^{21}$ and spray pyrolysis. ${ }^{22}$ Risch et al. reported an efficiency of $4.5 \%$, but could achieve a higher $V_{\mathrm{OC}}$ in comparison to the CdSreference. For the $\mathrm{Cu}_{2} \mathrm{ZnSnS}_{4}$ (CZTS)- $\mathrm{In}_{2} \mathrm{~S}_{3}$ interface a spikelike conduction band offset (CBO) of $0.41 \mathrm{eV}$ was reported, which is still in the desired range for high-efficiency solar cells. ${ }^{23}$ In another work, the $V_{\mathrm{OC}}$ was improved by $120 \mathrm{mV}$ in comparison to the CdS-reference. However, due to a very low photocurrent the efficiency was only $0.4 \%{ }^{24}$ With a sputtered $\mathrm{In}_{2} \mathrm{~S}_{3}$ buffer on a CZTS absorber both efficiency $(4.2 \%)$ and $V_{\mathrm{OC}}$ $(531 \mathrm{mV})$ were considerably higher than with CdS. ${ }^{25}$ For a CBDdeposited $\operatorname{In}_{2} \mathrm{~S}_{3}$ layer an efficiency of $6.9 \%$ was reported. ${ }^{26}$ The highest efficiency with an $\operatorname{In}_{2} \mathrm{~S}_{3}$ buffer so far is $7.6 \%$, which was achieved with CBD-deposited $\mathrm{In}_{2} \mathrm{~S}_{3}$ on a CZTSSe absorber. ${ }^{27}$ Most reports used an additional heat treatment that improved the interface by diffusion of $\mathrm{Cu}$ and $\mathrm{Na}$ into the buffer and In into the absorber material, respectively. ${ }^{26,28}$ For CZGSSe absorbers there are no reports about $\operatorname{In}_{2} \mathrm{~S}_{3}$ buffer layers so far. However, although CZGSSe has a higher band gap, the overall similarity to CZTSSe makes $\operatorname{In}_{2} \mathrm{~S}_{3}$ a reasonable and interesting choice as buffer material.

In Fig. 2 the solar cell parameters of solar cells with $\operatorname{In}_{2} \mathrm{~S}_{3}$ layer thicknesses from $3 \mathrm{~nm}$ to $28 \mathrm{~nm}$ are displayed as box plots. Note that these parameters were obtained without an additional heat treatment. For thin $\operatorname{In}_{2} S_{3}$ layers the short circuit current density $\left(J_{\mathrm{sC}}\right)$ is very low. It strongly increases, until at a film thickness of $7 \mathrm{~nm}$ saturation occurs. The $V_{\mathrm{OC}}$ reaches its maximum at $7 \mathrm{~nm}$ and decreases again for thicker films. For the fill factor $(\mathrm{FF})$ no clear trend is visible with slightly lower values for 5 and $21 \mathrm{~nm}$ film thickness. Thus the efficiency reaches its maximum at an $\mathrm{In}_{2} \mathrm{~S}_{3}$ thickness of only $7 \mathrm{~nm}$ with an average value of $2.5 \%$. A comparison with literature is difficult, since most other publications do not report the film thickness. In the case of Jiang $e t$ al. it was varied between 50 and $180 \mathrm{~nm}$ and was therefore considerably thicker. ${ }^{26}$

For the investigation of the effect of post-annealing all samples were subsequently annealed for $15 \mathrm{~min}$ on a hot plate in ambient atmosphere at temperatures of 180, 200 and $220^{\circ} \mathrm{C}$. For the sake of clarity, in Table 1 only the results with an $\operatorname{In}_{2} \mathrm{~S}_{3}$ layer thickness of $7 \mathrm{~nm}$ are shown, because they obtained the highest efficiencies. All solar cell parameters are increasing with heating temperature. However, with a gain of $53 \mathrm{mV}$ the effect is most pronounced for $V_{\mathrm{OC}}$ whilst the changes in $\mathrm{FF}$ and $J_{\mathrm{SC}}$ are rather small. The average efficiency after heating at $220{ }^{\circ} \mathrm{C}$ is $3.1 \%$ with a maximum value of $3.4 \%$. The improvements after post annealing are attributed to diffusion of and $\mathrm{Cu}$ and $\mathrm{Na}$ into the buffer, which is commonly reported for $\operatorname{In}_{2} \mathrm{~S}_{3}$ buffers. ${ }^{29} \mathrm{~A}$ comparison to

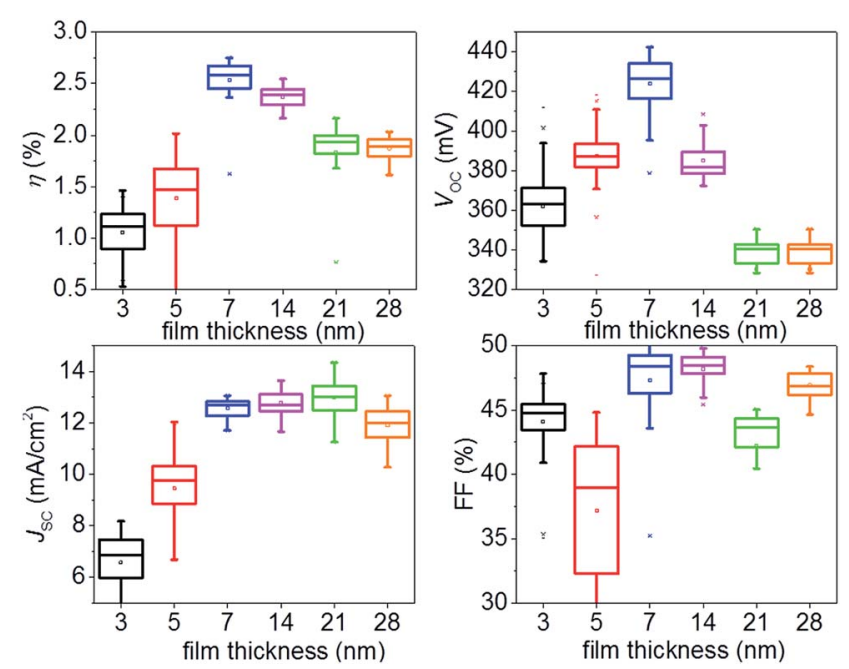

Fig. 2 Parameters of solar cells with a CZGSSe absorber and $\ln _{2} S_{3}$ buffer with buffer layer thicknesses between 3 and $28 \mathrm{~nm}$. 
Table 1 Average parameters and standard deviation of solar cells with a $7 \mathrm{~nm} \ln _{2} \mathrm{~S}_{3}$ buffer layer after subsequent annealing for $15 \mathrm{~min}$ in ambient atmosphere on a hot plate at different temperatures

\begin{tabular}{|c|c|c|c|c|}
\hline & As grown & $180^{\circ} \mathrm{C}$ & $200{ }^{\circ} \mathrm{C}$ & $220^{\circ} \mathrm{C}$ \\
\hline$\eta(\%)$ & $2.5 \pm 0.2$ & $2.7 \pm 0.3$ & $3.0 \pm 0.2$ & $3.1 \pm 0.3$ \\
\hline$V_{\mathrm{OC}}(\mathrm{mV})$ & $423 \pm 14$ & $446 \pm 14$ & $462 \pm 8$ & $476 \pm 7$ \\
\hline$J_{\mathrm{SC}}\left(\mathrm{mA} \mathrm{cm}^{-2}\right)$ & $12.6 \pm 0.4$ & $12.9 \pm 0.4$ & $13.3 \pm 0.5$ & $13.2 \pm 0.6$ \\
\hline $\mathrm{FF}(\%)$ & $47.3 \pm 3.3$ & $47.6 \pm 3.3$ & $49.0 \pm 2.0$ & $49.9 \pm 2.2$ \\
\hline
\end{tabular}

other buffer materials will be done later on in this manuscript.

\section{$\mathrm{Zn}(\mathbf{O}, \mathbf{S})$}

$\mathrm{Zn}(\mathrm{O}, \mathrm{S})$ is a promising buffer layer material for solar cells with CZTSSe absorbers since its elements are earth abundant, nontoxic and it offers a higher band gap than CdS which can lead to an increased absorption in the short wavelength regime. The band gap can be tuned from $3.3 \mathrm{eV}$ for pure $\mathrm{ZnO}$ to $3.6 \mathrm{eV}$ for pure ZnS with a minimal band gap for $50 \% \mathrm{ZnO}$ ("bowing") ${ }^{30}$ by varying the $[\mathrm{S}] /([\mathrm{S}]+[\mathrm{O}])$-ratio. This is necessary, because $\mathrm{ZnO}$ was reported to have an unfavourable cliff-like CBO with CZTSSe whereas ZnS was found to have a considerably spikelike $\mathrm{CBO}$ with a barrier of $1.1 \mathrm{eV} .^{27}$ Grenet et al. reported an efficiency of $5.8 \%$ for a $\mathrm{ZnS}(\mathrm{O}, \mathrm{OH})$ buffer prepared by $\mathrm{CBD} .{ }^{31}$ The performance is strongly influenced by metastabilities, since "before LS [light soaking] treatment almost no photovoltaic effect is observed". In a different work, no photocurrent could be obtained for a CZTS absorber and a $\mathrm{Zn}(\mathrm{O}, \mathrm{S})$ buffer, which is attributed to a high barrier of $0.9 \mathrm{eV}$ at the $\mathrm{CBO} .{ }^{24}$ However, no light soaking was performed. Ericson et al. demonstrated an efficiency of $4.6 \%$ for a CZTS/Zn(O,S) system (buffer deposited by ALCVD) with $[\mathrm{S}] /([\mathrm{S}]+[\mathrm{O}])=0.14$ and the activation energy increased with the $[\mathrm{S}] /([\mathrm{S}]+[\mathrm{O}])$-ratio. ${ }^{32}$ Recently, Neuschitzer et al. reported an efficiency of $6.5 \%$ for CBD-deposited $\mathrm{ZnS}(\mathrm{O}, \mathrm{OH})$ which is the highest value for a kesterite absorber. ${ }^{33}$

In this work, sputter-deposited $\mathrm{Zn}(\mathrm{O}, \mathrm{S})$ buffers from mixed targets with $[\mathrm{S}] /([\mathrm{S}]+[\mathrm{O}])$-ratios of 0.2 and 0.4 are used. These ratios are considerably lower than what is commonly used for CBD-based $\mathrm{Zn}(\mathrm{O}, \mathrm{S})$ layers for CIGS, where typical $[\mathrm{S}] /([\mathrm{S}]+[\mathrm{O}])-$ ratios are between 0.7 and $0.9 .^{34}$ However, a direct comparison between sputtering and CBD is different anyway, since depending on the concentration of precursor chemicals with the CBD-approach also $\mathrm{Zn}(\mathrm{OH})_{2}$ species can be formed ${ }^{18}$ which is not the case for sputtered $\mathrm{Zn}(\mathrm{O}, \mathrm{S})$.

The $J V$-characteristics under illumination of solar cells with $\mathrm{Zn}(\mathrm{O}, \mathrm{S})$ buffers from the targets with $[\mathrm{S}] /([\mathrm{S}]+[\mathrm{O}])$-ratios of 0.2 and 0.4 are displayed in Fig. 3. The solar cell with a buffer with $[\mathrm{S}] /([\mathrm{S}]+[\mathrm{O}])=0.2$ has an efficiency of $1.4 \%$ with $V_{\mathrm{OC}}=232 \mathrm{mV}$, $J_{\mathrm{SC}}=14.5 \mathrm{~mA} \mathrm{~cm}^{-2}$ and $\mathrm{FF}=42.1 \%$. In contrast, with $[\mathrm{S}] /([\mathrm{S}]+$ $[\mathrm{O}])=0.4$ an efficiency of $4.6 \%$ could be achieved with $V_{\mathrm{OC}}=$ $730 \mathrm{mV}, J_{\mathrm{SC}}=13.0 \mathrm{~mA} \mathrm{~cm}{ }^{-2}, \mathrm{FF}=48.3 \%$. The slightly higher $J_{\mathrm{SC}}$ of the sample with $[\mathrm{S}] /([\mathrm{S}]+[\mathrm{O}])=0.2$ can be explained by the higher band gap of the buffer that allows an increased absorption in the short-wave regime. Additionally, the huge difference in $V_{\mathrm{OC}}$ is remarkable. It might indicate an improved

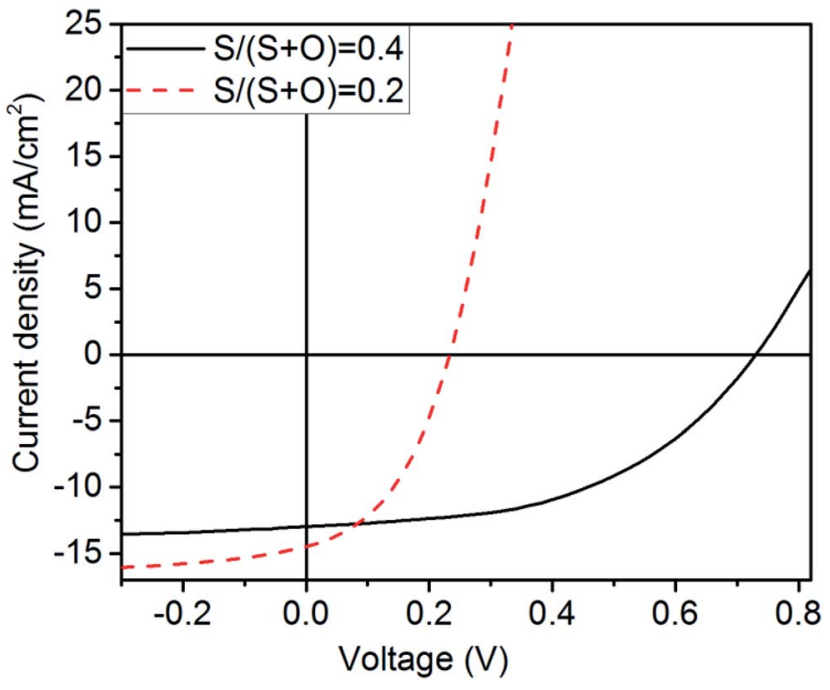

Fig. $3 \mathrm{~J}-\mathrm{V}$-characteristics of solar cells with $\mathrm{Zn}(\mathrm{O}, \mathrm{S})$ buffer under illumination.

band alignment and therefore less interface recombination for the $\mathrm{Zn}(\mathrm{O}, \mathrm{S})$ buffer with higher S-content. However, also other factors such as a different doping of the buffer layer or different tunnel recombination could influence the $V_{\text {OC. }}$.

Note that in contrast to some of the previously cited reports, no improvement of the solar cell efficiency was obtained after light soaking. However, this is not surprising since the $J-V$ characteristics do not have a kink as it was reported by Neuschitzer et al. before light soaking. ${ }^{33}$

\section{Comparison}

In this section the best sample types from each buffer material are compared. In detail that are (i) sputtered $\mathrm{Zn}(\mathrm{O}, \mathrm{S})$ with $[\mathrm{S}] /([\mathrm{S}]$ $+[\mathrm{O}])=0.4$ and a thickness of $40 \mathrm{~nm}$, (ii) CBD-deposited CdS with a thickness of approximately $50 \mathrm{~nm}$, (iii) ALCVD-deposited $\mathrm{In}_{2} \mathrm{~S}_{3}$ with a thickness of $7 \mathrm{~nm}$ and a subsequent heat treatment

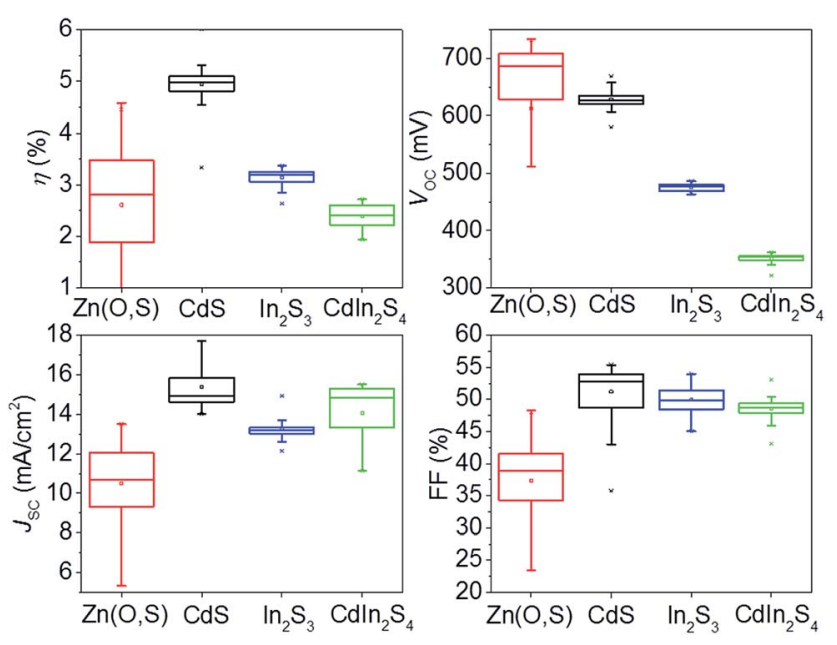

Fig. 4 Parameters of solar cells with a CZGSSe absorber and different buffer materials. 


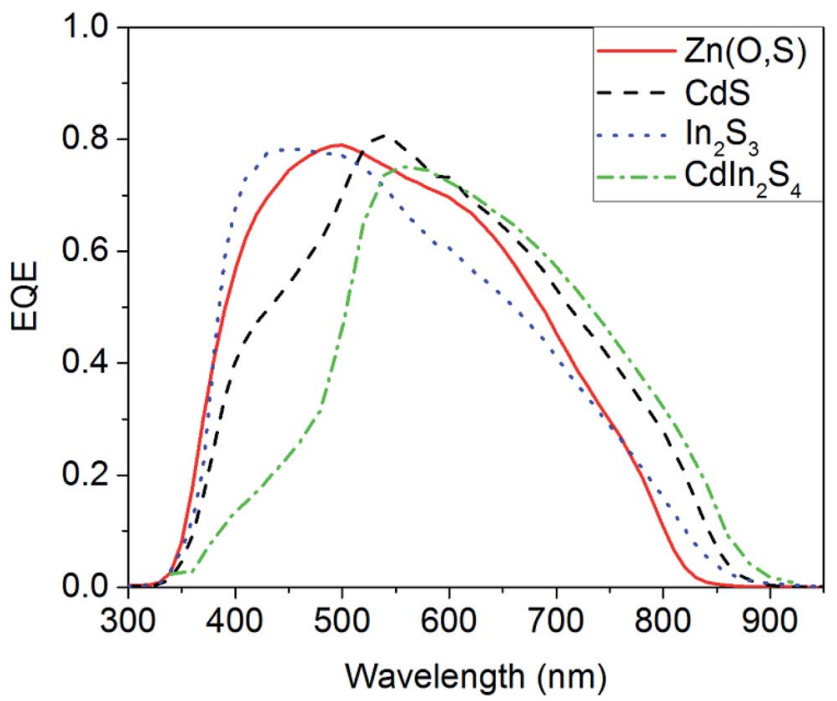

Fig. 5 EQE measurements of solar cells with CZGSSe absorber and different buffer layers.

for $15 \mathrm{~min}$ at $180{ }^{\circ} \mathrm{C}$ on a hot plate and (iv) coevaporated $\mathrm{CdIn}_{2} \mathrm{~S}_{4}$ with a thickness of $50 \mathrm{~nm}$.

The solar cell parameters for all buffer materials are compared as box plots in Fig. 4 . In terms of efficiency, solar cells with a CdS buffer clearly show the best performance with an average value of $5 \%$. All other materials only show average efficiencies around $3 \%$. However, solar cells with a $\mathrm{Zn}(\mathrm{O}, \mathrm{S})$ buffer could achieve $V_{\mathrm{OC}}$-values of up to $733 \mathrm{mV}$ which is clearly higher than all other buffer materials and indicates an improved absorber-buffer-interface. The average $V_{\mathrm{OC}}$ for $\operatorname{In}_{2} \mathrm{~S}_{3}$ and $\mathrm{CdIn}_{2} \mathrm{~S}_{4}$ is $475 \mathrm{mV}$ and $350 \mathrm{mV}$, respectively. On the other hand, $\mathrm{Zn}(\mathrm{O}, \mathrm{S})$ exhibits the lowest $\mathrm{FF}$ (37\% in comparison to around $50 \%$ for the other materials $)$ and $J_{\mathrm{SC}}\left(10.5 \mathrm{~mA} \mathrm{~cm}{ }^{-2}\right.$ in comparison to between 13 and $15 \mathrm{~mA} \mathrm{~cm}{ }^{-2}$ for the other materials). Especially in the case of $J_{\mathrm{SC}}$ this is surprising, since the used $\mathrm{Zn}(\mathrm{O}, \mathrm{S})$ should have a band gap of around $2.6 \mathrm{eV}^{35}$ which is higher than that of CdS and should therefore allow an increased absorption of photons in the short wavelength regime.

To investigate this in more detail, EQE measurements were performed (Fig. 5). In the short wavelength region the sample with $\mathrm{CdIn}_{2} \mathrm{~S}_{4}$ buffer shows by far the lowest absorption. On the contrary, the sample with $\mathrm{Zn}(\mathrm{O}, \mathrm{S})$ buffer indeed shows a considerably increased absorption between 400 and $500 \mathrm{~nm}$ in comparison to the CdS buffer. The same holds true for the sample with $\operatorname{In}_{2} \mathrm{~S}_{3}$ buffer. Note that according to literature the band gap of $\operatorname{In}_{2} \mathrm{~S}_{3}$ was found to vary between $2.25 \mathrm{eV}$ and $3.2 \mathrm{eV}$ depending on the deposition technique used. ${ }^{36}$ For films by ALCVD it was found to be $2.7 \mathrm{eV}^{37}$ and thus the increased absorption in the short wavelength regime is expected. It may additionally be mentioned that the very low film thickness of $7 \mathrm{~nm}$ also affects the absorption.

However, both $\mathrm{Zn}(\mathrm{O}, \mathrm{S})$ and $\operatorname{In}_{2} \mathrm{~S}_{3}$ suffer from strongly decreased collection in the long wavelength regime in comparison to $\mathrm{CdS}$ and $\operatorname{CdIn}_{2} \mathrm{~S}_{4}$. For this behaviour two possible reasons can be found. On the one hand, (i) CBDdeposited CdS is usually present not only at the interface, but also in the bulk of the absorber, where it can reach through small pinholes. There it is able to passivate grain boundaries which facilitates the electron transport and is beneficial for the carrier collection. ${ }^{38}$

On the other hand, (ii) the band gaps of the absorber layers discussed in this manuscript are found to be slightly different. A linear extrapolation from the squared plot of the EQE (see ESI $\dagger$ ) suggests $1.44 \mathrm{eV}$ with $\mathrm{CdIn}_{2} \mathrm{~S}_{4}$ buffer, $1.47 \mathrm{eV}$ with $\mathrm{CdS}$ and $1.54 \mathrm{eV}$ with $\mathrm{Zn}(\mathrm{O}, \mathrm{S})$. For the $\mathrm{In}_{2} \mathrm{~S}_{3}$ buffer the plot is not linear, which can be attributed to strong band tailing. Thus only a range between 1.49 and $1.54 \mathrm{eV}$ can be given. The reasons for this differences are not understood in detail yet. However, they might be linked to diffusion of Cd into the kesterite absorber, which can replace $\mathrm{Zn}$ and thereby decrease the band gap. ${ }^{39}$ This might explain the higher band gaps of CZGSSe absorbers with Cd-free buffer materials. Consequently, the increased absorption in the long wavelength regime with a $\mathrm{CdIn}_{2} \mathrm{~S}_{4}$ buffer could be explained by the lower band gap of the corresponding absorber.

To gain further understanding about the absorber-bufferinterface, temperature-dependent $J V$ characteristics were measured in a temperature range between $10{ }^{\circ} \mathrm{C}\left(17{ }^{\circ} \mathrm{C}\right.$ for $\mathrm{CdIn}_{2} \mathrm{~S}_{4}$ ) and $60^{\circ} \mathrm{C}$. From a linear extrapolation of the plot of $V_{\mathrm{OC}}$ versus temperature to $0 \mathrm{~K}$ the activation energy of the dominant recombination path $\left(E_{\mathrm{A}}\right)$ can be estimated. If it is smaller than the band gap, this is indicative of dominant interface recombination. ${ }^{40,41}$ The results are displayed in Table 2. The activation energies for all buffer materials are smaller than the band gap of the CZGSSe absorber, thus all solar cells should be limited by interface recombination. However, there are still distinct differences between the different buffer materials.

Since the band gaps are slightly different, the difference between $E_{\mathrm{G}}$ and $E_{\mathrm{A}}$ was calculated to allow a better comparison. Here with $193 \mathrm{meV}$ the CdS buffer shows the lowest difference indicating the best absorber-buffer interface. The $\mathrm{Zn}(\mathrm{O}, \mathrm{S})$

Table 2 Band gap, open circuit voltage, activation energy of the dominant recombination path and efficiency of the best solar cells with different buffer materials. From those parameters, the $V_{\mathrm{OC}}$-deficit $E_{\mathrm{G}}-V_{\mathrm{OC}}$ and the difference between $E_{\mathrm{G}}$ and $E_{\mathrm{A}}$ are calculated

\begin{tabular}{|c|c|c|c|c|c|c|}
\hline & $E_{\mathrm{G}}(\mathrm{eV})$ & $V_{\mathrm{OC}}(\mathrm{mV})$ & $E_{\mathrm{G}} / q-V_{\mathrm{OC}}(\mathrm{mV})$ & $E_{\mathrm{A}}(\mathrm{meV})$ & $E_{\mathrm{G}}-E_{\mathrm{A}}(\mathrm{meV})$ & $\eta(\%)$ \\
\hline $\mathrm{Zn}(\mathrm{O}, \mathrm{S})$ & 1.54 & 730 & 810 & 1307 & 233 & 4.6 \\
\hline $\mathrm{CdS}$ & 1.47 & 617 & 853 & 1277 & 193 & 6.0 \\
\hline $\mathrm{CdIn}_{2} \mathrm{~S}_{4}$ & 1.44 & 354 & 1086 & 820 & 620 & 2.6 \\
\hline
\end{tabular}


buffer only has a slightly higher difference between $E_{\mathrm{G}}$ and $E_{\mathrm{A}}$ $\left(233 \mathrm{meV}\right.$ ) whereas $\operatorname{In}_{2} \mathrm{~S}_{3}$ and $\mathrm{CdIn}_{2} \mathrm{~S}_{4}$ seem to have a considerably lower interface quality.

However, another option to compare the different buffer materials is the $V_{\mathrm{OC}}$-deficit $E_{\mathrm{G}}-V_{\mathrm{OC}}$ that is also displayed in Table 2. In this case we get a slightly different picture, since $\mathrm{Zn}(\mathrm{O}, \mathrm{S})$ has the lowest $V_{\mathrm{OC}}$-deficit of $810 \mathrm{mV}$ (which is, of course, still very high). The CdS buffer shows a slightly higher $V_{\mathrm{OC}}$-deficit of $853 \mathrm{mV}$, while $\operatorname{In}_{2} \mathrm{~S}_{3}$ and $\operatorname{CdIn}_{2} \mathrm{~S}_{4}$ have values above $1 \mathrm{eV}$.

In summary, the comparison of $E_{\mathrm{G}}-E_{\mathrm{A}}$ and $V_{\mathrm{OC}}$-deficit suggests an apparent contradiction since either $\mathrm{Zn}(\mathrm{O}, \mathrm{S})$ or $\mathrm{CdS}$ seem to have the best interface quality of the investigated buffer materials. For further increasing the solar cell efficiency the most crucial factor is the absorber itself which has to be optimized. For an improved buffer layer a combination of a very thin CdS-layer by CBD to passivate defects in the bulk and a $\mathrm{Zn}(\mathrm{O}, \mathrm{S})$ layer on top might be interesting. A similar "hybrid buffer" has been reported for a combination of CdS and $\operatorname{In}_{2} S_{3}$ where considerable improvements in $V_{\mathrm{OC}}$ and efficiency could be obtained. ${ }^{42,43}$

\section{Conclusions}

Thin-film solar cells with a wide-gap kesterite CZGSSe absorber and four different buffer layers, namely CdS, $\mathrm{Zn}(\mathrm{O}, \mathrm{S}), \mathrm{In}_{2} \mathrm{~S}_{3}$ and $\mathrm{CdIn}_{2} \mathrm{~S}_{4}$, have been prepared. All buffer materials resulted in functional devices. For $\operatorname{In}_{2} \mathrm{~S}_{3}$ different film thicknesses were compared with the best efficiency of $3.4 \%$ for an only $7 \mathrm{~nm}$ thick buffer layer. The best working device was prepared with a CdS buffer and resulted in an efficiency of $6.0 \%$, which is the highest value for CZGSSe absorbers. However, with $\mathrm{Zn}(\mathrm{O}, \mathrm{S})$ a higher open circuit voltage and a higher activation energy of the dominant recombination path could be obtained, which indicates a better band alignment compared to CdS.

\section{Conflicts of interest}

There are no conflicts of interest to declare.

\section{Acknowledgements}

The authors thank Guy Brammertz and Bart Vermang for fruitful discussions. This work was performed within the SWInG project that has received funding from the European Union's Horizon 2020 research and innovation programme under grant agreement No. 640868.

\section{Notes and references}

1 D. B. Khadka and J. Kim, J. Phys. Chem. C, 2015, 119, 17061713.

2 T. J. Huang, X. Yin, G. Qi and H. Gong, Phys. Status Solidi $R R L, 2014,8,735-762$.

3 S. Giraldo, M. Neuschitzer, T. Thersleff, S. Lopez-Marino, Y. Sanchez, H. Xie, M. Colina, M. Placidi, P. Pistor,
V. Izquierdo-Roca, K. Leifer, A. Perez-Rodriguez and E. Saucedo, Adv. Energy Mater., 2015, 5, 1501070.

4 A. D. Collord and H. W. Hillhouse, Chem. Mater., 2016, 28, 2067-2073.

5 E. Garcia-Llamas, J. M. Merino, R. Serna, X. Fontane, I. A. Victorov, A. Perez-Rodriguez, M. Leon, I. V. Bodnar, V. Izquierdo-Roca and R. Caballero, Sol. Energy Mater. Sol. Cells, 2015, 158, 147-153.

6 Q. Guo, G. M. Ford, W. Yang, C. J. Hages, H. W. Hillhouse and R. Agrawal, Sol. Energy Mater. Sol. Cells, 2012, 105, 132-136.

7 D. B. Khadka and J. Kim, CrystEngComm, 2013, 15, 1050010509.

8 L. Huang, H. Deng, J. He, X. Meng, J. Tao, H. Cao, L. Sun, P. Yang and J. Chu, Mater. Lett., 2015, 159, 1-4.

9 M. Buffiere, H. ElAnzeery, S. Oueslati, K. Ben Messaoud, G. Brammertz, M. Meuris and J. Poortmans, Thin Solid Films, 2015, 582, 171-175.

10 H. Matsushita, T. Ochiai and A. Katsui, J. Cryst. Growth, 2005, 275, e995-e999.

11 K. Timmo, M. Kauk-Kuusik, M. Altosaar, J. Raudoja, T. Raadik, M. Grossberg, T. Varema, M. Pilvet, I. Leinemann, O. Volobujeva and E. Mellikov, 28th European Photovoltaic Solar Energy Conference and Exhibition, 2013.

12 T. Schnabel, M. Seboui and E. Ahlswede, RSC Adv., 2017, 7, 26-30.

13 S. Sahayaraj, G. Brammertz, B. Vermang, T. Schnabel, E. Ahlswede, Z. Huang, S. Ranjbar, M. Meuris, J. Vleugels, J. Poortmans and G. Brammertz, Sol. Energy Mater. Sol. Cells, 2017, 171, 136-141.

14 J. Li, M. Wei, Q. Du, W. Liu, G. Jiang and C. Zhu, Surf. Interface Anal., 2013, 45, 682-684.

15 R. Haight, A. Barkhouse, O. Gunawan, B. Shin, M. Copel, M. Hopstaken and D. B. Mitzi, Appl. Phys. Lett., 2011, 98, 253502.

16 Q. Shu, J. Yang, S. Chen, B. Huang, H. Xiang, X. Gong and S. Wei, Phys. Rev. B: Condens. Matter Mater. Phys., 2013, 87, 115208.

17 P. Jackson, R. Wuerz, D. Hariskos, E. Lotter, W. Witte and M. Powalla, Phys. Status Solidi RRL, 2016, 10, 583-586.

18 D. Hariskos, P. Jackson, W. Hempel, S. Paetel, S. Spiering, R. Menner, W. Wischmann and M. Powalla, IEEE J. Photovolt., 2016, 6, 1321-1326.

19 S. Spiering, A. Nowitzki, F. Kessler, M. Igalson and H. Abdel Maksoud, Sol. Energy Mater. Sol. Cells, 2016, 144, 544-550.

20 E. Gautron, T. Lepetit, S. Harel, L. Arzel, L. Assmann, A. Frelon, R. Andrade, S. Sadewasser, T. Douillard and T. Epicier, Heterointerfaces TEM characterization of buffer layers in KF treated CIGS solar cells. Towards a new buffer layer?, European Microscopy Congress, 2016, p. 898.

21 M. Buffiere, G. Brammertz, S. Sahayaraj, M. Meuris, J. Poortmans and N. Barreau, IEEE Phot. Spec. Conf., 2015.

22 D. B. Khadka, S. Kim and J. Kim, J. Phys. Chem. C, 2015, 119, 12226-12235. 
23 X. Liu, Y. Feng, H. Cui, F. Liu, X. Hao, G. Conibeer, D. B. Mitzi and M. Green, Prog. Photovoltaics, 2016, 24, 879-898.

24 C. Yan, F. Liu, N. Song, B. K. Ng, J. A. Stride, A. Tadich and X. Hao, Appl. Phys. Lett., 2014, 104, 173901.

25 P. Bras and J. Sterner, IEEE Phot. Spec. Conf., 2014.

26 F. Jiang, C. Ozaki, O. Gunawan, T. Harada, Z. Tang, T. Minemoto, Y. Nose and S. Ikeda, Chem. Mater., 2016, 28, 3283-3291.

27 D. A. R. Barkhouse, R. Haight, N. Sakai, H. Hiroi, H. Sugimoto and D. B. Mitzi, Appl. Phys. Lett., 2012, 100, 193904.

28 D. Hariskos, S. Spiering and M. Powalla, Thin Solid Films, 2005, 480, 99-109.

29 S. Spiering, L. Bürkert, D. Hariskos, M. Powalla, B. Dimmler, C. Giesen and M. Heuken, Thin Solid Films, 2009, 517, 23282331.

30 M. Buffiere, S. Harel, C. Guillot-Deudon, L. Arzel, N. Barreau and J. Kessler, Phys. Status Solidi A, 2014, 212, 282-290.

31 L. Grenet, P. Grondin, K. Coumert, N. Karst, F. Emieux, F. Roux, R. Fillon, G. Altamura, H. Fournier and P. Faucherand, Thin Solid Films, 2014, 564, 375-378.

32 T. Ericson, J. J. Scragg, A. Hultqvist, J. T. Watjen, P. Szaniawski, T. Torndahl and C. Platzer-Bjorkman, IEEE J. Photovolt., 2014, 4, 465-469.

33 E. Saucedo, A. Perez-Rodriguez, M. Neuschitzer and K. Lienau, J. Phys. D: Appl. Phys., 2016, 49, 125602.
34 D. Hariskos, R. Menner, P. Jackson, S. Paetel, W. Witte, W. Wischmann, M. Powalla, L. Bürkert, T. Kolb, M. Oertel, B. Dimmler and B. Fuchs, Prog. Photovoltaics, 2012, 20, 534-542.

35 A. Polity, B. K. Meyer, T. Krämer, C. Wang, U. Haboeck and A. Hoffmann, Phys. Status Solidi A, 2006, 203, 2867-2872.

36 F. Mesa, W. Chamorro and M. Hurtado, Appl. Surf. Sci., 2015, 350, 38-42.

37 S. Spiering, D. Hariskos, M. Powalla, N. Naghavi and D. Lincot, Thin Solid Films, 2003, 431, 359-363.

38 M. Werner, D. Keller, S. G. Haass, C. Gretener, B. Bissig, P. Fuchs, F. La Mattina, R. Erni, Y. E. Romanyuk and A. N. Tiwari, ACS Appl. Mater. Interfaces, 2015, 7, 1214112146.

39 M. Altosaar, J. Raudoja, K. Timmo, M. Danilson, M. Grossberg, J. Krustok and E. Mellikov, Phys. Status Solidi A, 2008, 205, 167-170.

40 V. Nadenau, U. Rau, A. Jasenek and H. W. Schock, J. Appl. Phys., 2000, 87, 584-593.

41 M. Turcu, O. Pakma and U. Rau, Appl. Phys. Lett., 2002, 80, 2598.

42 H. Hiroi, N. Sakai, T. Kato, and H. Sugimoto, IEEE Phot. Spec. Conf., 2013.

43 C. Yan, F. Liu, K. Sun, N. Song, J. A. Stride, F. Zhou, X. Hao and M. Green, Sol. Energy Mater. Sol. Cells, 2016, 144, 700706. 